\title{
The Rise of China and Its Implications to Northeast Asia
}

\author{
Wai Ting \\ Advanced Institute for Contemporary China Studies \& \\ Department of Government and International Studies, \\ Hong Kong Baptist University \\ AAB 1110, 11/F, \\ Academic and Administration Building \\ Baptist University Road Campus, Hong Kong \\ E-mail: tingwai@associate.hkbu.edu.hk
}

Abstract: The rise of China has aroused heated debates on whether the country would become the "revisionist" power in challenging the supreme position of the "status quo" power, the United States. This paper aims to examine whether the rise of China would, firstly, empower Beijing to solve the long-term crisis in the Korean Peninsula, and secondly, complicates the picture in solving the difficult historical and political issues in Sino-Japanese relations. It is argued that the increasing economic and military capabilities of China are not instrumental in fostering significant changes within North Korea and in monitoring the external behavior of its leaders. A more nationalistic China which lacks soft power also hinders a favorable solution to the challenges of Sino-Japanese relations.

Keywords: balancer, brinkmanship, Diaoyu Islands, international norms, nationalism, Pivot to Asia, Rebalancing, revisionist power, Six-Party Talks, soft power, status quo power

\section{Introduction}

The rise of China has attracted worldwide attention since the end of the last century. The central question is whether the "revisionist" power, China, would challenge the "status quo" power, the US, in the new millennium. Going back to the 20th century, the then "revisionist" powers like Germany and Japan challenged the "status quo" powers, Great Britain and France, as they were 
discontented with the dominance of the international political order by the status quo powers. The results were two "total wars". Though the pessimistic view of John Mearsheimer, epitomized by the label "offensive realism", is not necessarily shared by many scholars (especially scholars in China) during this "power transition" process, many observers argue that the possibility of potential conflicts between China and the US cannot be dissipated.

China's rise is accompanied by two major phenomena noted by scholars from both inside and outside China. First, the lack of soft power and the vicissitudes of developing soft power in China make it difficult for Beijing to appease and convince the whole global community that the nation is going to become more advanced and civilized so as to benefit the whole world. The remarkable increase in economic and military capabilities could only frighten its neighbors if China is not able to accomplish major achievements in developing its culture, values, ideas and institutions to make China attractive to the whole world (Ting, 2009). Second, the People's Republic of China (PRC) does not seem to have a coherent and well-thought "grand strategy" in its foreign policies corresponding to its rapid rise (Ting, 2013a). Beijing urgently needs to consider the fundamental questions relating to its grand strategy. For instance, should the legacy of Deng Xiaoping, Taoguang Yanhui ('Bide the time and conceal the abilities') be maintained, taking the form of a low-profiled approach to foreign policies, or does the Chinese government need to be more high-profile and assertive in world affairs especially in regional issues where its core interests are at stake, with an influence commensurate with its rapidly growing capabilities? How to build up a better image of China in the world nowadays depends not only on the principles and practice of Chinese diplomacy, but also on the "performance" of the Chinese companies as well as the Chinese people who flood the world in pursuit of business, tourism, studies, etc. How does the Chinese government facilitate a better image among people all over the world, given the fact that the opinions of the outside world towards China tend to be more negative than earlier surveys? How to "democratize international relations", in order to achieve a breakthrough in the "uni-multipolar" world has been a long-term goal of Chinese diplomacy since the end of Cold War. It is another major theme that should be included in conceptualizing the "grand strategy" of China.

Parallel to China's rise is the relative decline of the US. After ceding its place as the number one producer of industrial products to China, the US also ceded its position as the number one trading nation to China in 2013. Its status as the biggest economic entity in the world will likely be ceded to China by 2020 (Lin, 2013, p. 16). In 2014, the number of tourists from China who travel abroad was greater than the number of tourists from the US. Facing the rise of China, people 
have been talking about "Chimerica" or G-2, and Chinese scholars as well as leaders have launched the idea of a "new type of great power relationship" since 2012. They would seek to steer away from the fatalistic prediction assumed by the power transition theory that the newly emergent power, the revisionist power, will seriously challenge leadership and dominance of the status quo power, thus resulting in wars. It goes without saying that in the near future China will not be able to catch up with the US in terms of high-technology development, scientific innovation and military capabilities, as the cultural-social atmosphere as well as education are not so well suited to creative ideas owing to the lack of liberty. Washington, on the other hand, has had to cut government expenditure given the enormous debts accumulated over the past years, thus restricting its freedom to maneuver in foreign security actions. The policy of "rebalancing to Asia", seen as a synonym of "pivot to Asia", is perceived in Asia as the dominating thinking of the US leaders today who wish to maintain and consolidate the American role as "balancer" or "stabilizer" in the changing regional balance of power caused by the rapid growth of China. In reality, facing the enormous budget cut in defense expenditure, the US must reduce some components of its military forces, while shifting the focus of its national defense. Rebalancing is simply a result of limited and reduced resources, imposed by the US Budget Control Act 2011 (Liu, 2013, p. 87). Under the leading principle of rebalancing, the Washington administration has to decide on how to make the difficult choices to maximize its diminishing expenditure and best secure its national defense; some components of military power may need to be developed further, while some other components will need to be cut. Geographically, Washington has to "withdraw" its armed forces from the Middle East and put more emphasis on the Asia-Pacific region (Department of Defense, 2014). This practice is already well known as the "pivot to Asia" policy. Rebalancing is the result of diminishing budget in national defense, so it is also the symbol of relative decline of the US. ${ }^{1}$

This paper aims to answer two sets of research questions. First, how does the rise of China, which results in strengthening China's economic and military capabilities, empower the Beijing authorities to solve the long-term crisis in the Korean Peninsula? Investigating the North Korea crisis further, would it

\footnotetext{
1 Rebalancing is the policy needed to cope with the diminishing defense budget in the US. According to the Quadrennial Defense Review 2014 (Department of Defense, 2014), rebalancing will be proceeded in various ways: rebalancing for a broad spectrum of conflicts, rebalancing the counter-terrorism efforts, rebalancing and sustaining the US presence and posture abroad to protect US national security interests, rebalancing capability, capacity and readiness within the Joint Force, rebalancing within the Army, and rebalancing within the Department of Defense (cutting costs in some areas).
} 
be possible for the two great powers, US and China, to collaborate in pressing North Korea to succumb to the conditions jointly laid down by the two in order to maintain stability on the Peninsula? Or, on the contrary, is the North Korean regime strategic in continuing its nuclearization, as it stands to benefit from the divergences between China and the US? Second, does the rise of China complicate the picture in solving the difficult historical and political issues in Sino-Japanese relations, as a more nationalistic and overly confident China would empower the regime to become more assertive in its relationship with the neighbors, and the relative decline of Japan in relation to China would thus become an impetus for the revival of Japanese nationalism, thus paving the way for nationalist rivalries between the two countries?

\section{China's policies towards North Korea}

The former President of South Korea, Park Geun-Hye, has a somewhat different policy vis-à-vis North Korea in comparison to her predecessor President Lee Myung-bak. The policy of President Park can be summarized as a "sweeter carrot and harder stick" policy. On the one hand, she has proposed to ameliorate the relationship with North Korea, based on the simple reason that people of the same race should cooperate among themselves despite any ideological, historical and political divergences. She has no hesitation to offer assistance to North Korea on humanitarian grounds. On the other hand, she makes it very clear that if the DPRK instigates further provocations using violence, Seoul will definitely riposte with prompt and forceful actions. In other words, the carrot offered to North Korea should be sweeter, while the use of stick, if necessary, should be much harder and stronger and employed without any hesitation (Park, 2013, p. 23).

Even though China is commonly seen as occupying a pivotal role in solving the Korean Peninsula crisis, as it is indeed the only power that continues to offer assistance to North Korea, China's policy towards North Korea is caught in a dilemma. The Chinese leadership is not able to find the best way out from the domestic divergence between the so-called "traditionalists" and the "strategists" among the Chinese strategic thinkers. On the one hand, Beijing has never wished to apply overly stringent pressure on the Pyongyang government, as Beijing is totally unwilling to see the collapse of the North Korean regime. Under the influence of the "traditionalists", who are mainly composed of scholars and strategic analysts in the northeastern provinces of China, in addition to 
government officials of this region and military leaders, Beijing seeks to offer assistance to Pyongyang, which includes mainly food, energy and industrial machinery. The energy is supplied in the form of crude oil as well as assistance in building electricity generating companies. The collapse of the Pyongyang regime will inevitably lead to the absorption of the North by South Korea. A reunified Korean Republic with a democratic system that continues to be an ally of the US with the stationing of American soldiers is considered to be totally unacceptable in the eyes of these Chinese observers. The continual existence of the DPRK as a kind of buffer is seen as crucial for the Chinese security, as these observers are mindful of the overwhelming influence of the US in Northeast Asia. They stress that the nuclear question provides a "handle" for the US to realize its strategic and security objective. The US will not be satisfied with the denuclearization of North Korea, as their main concern is to induce fundamental change in the Korean Peninsula order, that is, to extend its sphere of influence and strategic deployment towards the Yalu River so as to press against China (Wang, 2013, p. 44). This is the reason why Beijing government opposed to the joint military naval exercises at the Yellow Sea between the US and South Korea after the DPRK launched its missile on 12 December 2012 and exploded its nuclear device for the third time on 12 February 2013. Beijing's warning to all the countries "not to create trouble outside our home door" is directed not only against Pyongyang, but also to Seoul and Washington.

However, the rescue of North Korea offered by the Chinese government in times of critical crises helps sustain the Pyongyang regime, which was then able to launch other "brinkmanship" activities against its three powerful adversaries, the US, Japan and South Korea, thus creating ongoing instability in the Korean Peninsula. There are two kinds of crises on the Korean Peninsula: those launched by the Pyongyang regime, such as missile launches or nuclear tests under the pretext of national security, and the domestic crises that DPRK needs to overcome due to its inexpedience in governance and mismanagement in macroeconomic control. After being rescued by China in solving its domestic crises, the North Korean authorities would proceed to initiate crises again for its neighbors so as to secure the maximum benefits possible. The simple corollary for China's actions is that if the PRC declines to offer assistance to North Korea, or stands beside US in sanctioning the Pyongyang regime, Pyongyang's freedom to maneuver will be very limited. It may go bankrupt or collapse, or to avoid this it may need to abide by what the neighbors and international society prescribe. However, this strategy has never been considered as a viable choice of the Beijing authorities, and the Xi Jinping regime does not seem to deviate from the "traditionalist" line of thought. 
According to the "strategists" line of thinking, the major flaw in Chinese policies towards North Korea is that among the strategic goals of China, stability of the Peninsula always overrides denuclearization (Zhang, 2013). The "strategists" maintain the idea that, domestically speaking, the DPRK government has done nothing beneficial for the North Korean people, while its external actions always create crises for its neighbors, including China. The regime itself is the major source of instability. What the North Korean regime has been doing is detrimental to Chinese national interests as well. Why then should China help a nation that consistently creates instabilities in China's border areas? The "traditionalists" put emphasis on stability as the primordial goal of China's Korea policy. But does this mean stability of the DPRK regime, or stability of the Korean Peninsula? If the source of instability of the Korean Peninsula is the North Korean regime, consolidating the regime or making the regime more stable and robust might mean inducing more instability to the whole Peninsula.

The so-called strategists can best be represented by a prominent Chinese expert in North Korean studies, Zhang Liangui, the professor of International Strategic Studies at the Central Party School, Beijing. In one of his papers, Zhang mentions four scenarios regarding the future of the Korean Peninsula in relation to the nuclearization of North Korea, and in no circumstances is China placed in a favorable position as a result of nuclearization (Zhang, 2013, p. 24). According to Zhang, the US' freedom to maneuver is much greater than that of China or North Korea. There are two strategic choices for Washington: either take forceful actions against the nuclearization of North Korea or abandon the policy of denuclearization commonly agreed upon by all the neighbors. For the first choice, if China decides to participate in any joint actions adopting compelling actions against North Korean nuclearization, the US would create a counter-proliferation united front against the DPRK. Thereafter the United Nations Security Council, under the joint approval of both US and China, could pass a resolution "not to exclude any choice" in order to press Pyongyang to abandon its nuclear forces. If the North Korean regime abandons its nuclear power under the threat of extremely severe sanctions, then denuclearization can be achieved. If the regime continues to promote its nuclear development, Washington might try to contain or isolate North Korea, and even consider using military forces to destroy the nuclear facilities of DPRK. If the PRC does not want to join the US on such forceful actions (from sanctions to warfare), as Beijing may think that stability of the Korean Peninsula (or simply stability or at least survival of the Pyongyang regime) prevails so no forceful means should be considered, then the US might simply unite various nations to act upon North Korea, without seeking even the approval of the Security Council. The final 
solution to the Korean Peninsula might then totally exclude the participation of China, even though Chinese interests are at stake.

For the second choice, if Washington abandons its policy of denuclearization, this means the formal recognition of North Korea as a nuclear power. The US might simply adopt a laissez-faire attitude by leaving the North Korean nuclear question to neighboring countries. This prevailing isolationist attitude of the US is accompanied by the reality that Washington is not afraid of the nuclear threat from Pyongyang, as the rudimentary nuclear forces of the latter are not able to inflict substantial damage on the US continent. The American government might even consider achieving an agreement with the North Korean authorities, so as to minimize the potential "harm" incurred. It has already been proposed by Pyongyang that it is possible to limit the horizontal proliferation (exporting nuclear materials and technology to other countries) and vertical proliferation (developing more and better nuclear weapons), and not to fabricate ICBM, in exchange for the US recognizing DPRK's nuclear status. If such an agreement were accepted by the US, then the North Korean nuclear forces only threaten the surrounding countries of the Peninsula. This can be considered as a setback for Washington in its counter-proliferation efforts, but indeed this is the worst scenario for Beijing (Zhang, 2013, p. 24).

In a nutshell, it is in the common interests of both Washington and Beijing to have a denuclearized Korean Peninsula, and only by close cooperation of the two great powers can this be achieved. Thus, the first scenario of the first choice is the most effective way to solve the North Korean nuclear problem forever. However, as the dominant thinking of the Chinese leaders is characterized by opposition to the overwhelming presence of the US in the Asia-Pacific region where it allegedly uses its superior power to act as a counterweight to the rise of China, it is difficult, if not impossible, to imagine that a scenario of US-China cooperation could happen. Collaborating with Washington in forcing China's closed ally to abolish its lethal weapons is definitely out of consideration of the "traditionalists" in Chinese strategic community. Nevertheless, the remaining three scenarios are absolutely detrimental to Chinese national interest. If the US destroys the DPRK nuclear force unilaterally (with the support of other powers except China), that means the denuclearization of North Korea is achieved without Chinese contribution. If the US accepts DPRK as a nuclear power and deliberately leaves the nuclear question to the Asian powers, China has to face the gruesome reality of an even more challenging security environment. North Korea is added to the two nuclear powers of India and Pakistan. This is a frightening prospect. 
Indeed, the analysis of Zhang reveals the shortfall in China's North Korea policy. The North Korean leaders know how to maneuver skillfully between the US and China. They benefit enormously from China's continual support, which provides indispensable assurance of the survival and stability of the Pyongyang regime. With such a guarantee, the regime is thus able to proceed towards becoming a nuclear power, and apparently all kinds of diplomatic actions initiated by the neighboring powers are unable to obstruct its determination to nuclearize, an ambition that has been underway since the nineties. The PRC is really caught in a paradox. Its policy is to have a denuclearized Korean Peninsula, but it continues to support the Pyongyang regime, enabling it to sustain its survival, which is the necessary condition for the North Korean leaders to develop nuclear armaments. A stable DPRK would lead to a more unstable Korean Peninsula. The central question is that the Chinese efforts to consolidate the stability of the North Korean regime simply enhance instability in the whole Korean Peninsula, as Pyongyang is able to develop its missile technology and nuclear weapons after its survival and security can be well assured.

It is clear that "certain elements within the constellation of Chinese foreign and security policy seem to be gaining an upper hand in shaping policy toward North Korea. They include individuals and institutions related to CCP international relations and propaganda bodies, the Chinese military and internal security apparatus, provincial governments in China's northeast, and companies with growing economic interests in North Korea." (Gill, 2011, p. 8) These people can be roughly categorized as "traditionalists" as mentioned above. They are more concerned with stability within North Korea, and they gain an upper hand in influencing the top decision-makers, as "party bodies and the military are far more experienced and effective as bureaucratic leaders in having their voices heard and heeded" (Gill, 2011, p. 8). The common ideological background in the past as well as the comrade relationship built during the Korean War still matters in the thinking of the "traditionalists". Moreover, those traditionalists that appear to be more conservative as they would not accept a radical change of status quo within North Korea, are keen to make sure that "adversary powers" (which means US and Japan) are not in a position to control the whole Korean Peninsula. So, a Chinese scholar even advocates the role of "balancer" and "coordinator" to be played by China to check upon the actions of these foreign powers with vested interests (Zhu, 2011). On the contrary, the so-called "strategists" are those "progressive or more internationalist advocates for a more constructive approach of cooperation with concerned foreign partners" (Gill, 2011, p. 8). Their influence is nevertheless somewhat limited, as the aforementioned "traditionalists" tend to adopt a more realistic attitude. From 
the perspective of "strategists", it is certainly in China's interest to have a stable DPRK hopefully evolving towards economic reform. But strategically speaking, if what Pyongyang is doing is detrimental to Chinese national interests, then cooperation with other concerned foreign powers to enforce common actions against the North Korean nuclear armaments should not be excluded as a major strategic choice.

The above discussion inevitably leads us to a crucial question. Does this mean that China has to succumb to a tacit consent to North Korea as a nuclear power? It goes without saying that this is contradictory to China's strategic consideration, but the appeasing attitude of Beijing authorities is helping to sustain the Pyongyang regime, which is then able to pursue its long-term strategic goal of gradually becoming a credible nuclear power. It can be argued that the DPRK leaders ably and calculatingly play the game between China and the US (Zhang, 2013).

If there is no other way to denuclearize North Korea, then neighboring countries have to think about how to accommodate a nuclearized DPRK. There have already been discussions on returning the US tactical nuclear weapons to South Korea so as to enhance deterrence against North Korea, or at least to improve bargaining leverage. Some South Koreans even think of developing nuclear weapons by themselves as a security guarantee since the US nuclear umbrella might not be totally reliable (Dalton \& Yoon, 2013).

Both Chinese and US authorities are worrying about the future directions of the Kim Jong-un administration. His father Kim Jong-il had developed superb expertise in launching crises and managing the continuous brinkmanship activities to seek the maximum benefits for the national interests of North Korea. The brutal purge of the former leaders by Kim Jong-un, especially the execution of his uncle Jang Song-thaek and his extended family members as well as their entourage, serves to eliminate those leaders who are considered to be menacing the Kim Jong-un rule (Wen Wei Po, 2014). But it may also reflect the lack of confidence of the young Kim, whose inexperienced performance in economic development and diplomatic actions may lead to further deterioration of the North Korean domestic situation. A possible implosion of the system might be the result of economic collapse, as Jang already warned in his last words, that Kim has no way to eliminate the enormous difficulties in the national economy and people's livelihood (Ta Kung Pao, 2013). Increasing uncertainties in North Korea are likely and have aroused serious anxieties in both the US and PRC. Though it is impossible to arrive at joint actions of the two powers vis-à-vis the North Korean crisis, it is imperative for Washington and Beijing to have 
more exchanges, and to consider serious actions that could reduce the threat and danger originated from the future hostile actions of North Korea or the possible collapse of the regime.

China persistently emphasizes the significance of solving the problems of Korean Peninsula by diplomatic and peaceful means. But all six rounds of the Six-Party Talks have proved to be a failure. Pyongyang leaders have created an illusion that the crises could be solved through diplomacy, but in fact they never stopped their research into nuclear armaments, especially the enriched uranium process. So, the Six-Party Talks only served the purpose of buying time for the DPRK authorities in the production of fissile materials as well as developing its nuclear technology.

The series of events since the sudden death of Kim Jong-il in late 2011 have demonstrated the helplessness of China in appeasing the situation on the Korean Peninsula. Already in April 2012, the right to possess nuclear armaments was written into the DPRK Constitution. In the same month, Pyongyang failed its attempt to launch a satellite. However, later that year, on 12 December 2012, it succeeded in launching the satellite which demonstrated that the country has well and truly acquired missile technology. Since possession of this technology is against United Nations Security Council Resolution 1718 passed in October 2006 after the first North Korean nuclear explosion, and also Resolution 1874 after the second nuclear test in May 2009, international society condemned the move. The Security Council eventually passed Resolution 2087 on 22 January 2013, imposing "mild" sanctions against North Korea. In fact, the Resolution only repeats the contents of the previous two resolutions. The next day, Pyongyang condemned China. It announced that the 19 September document which resulted from the Six-Party Talks would become void, and its commitment to denuclearization ended.

Just two months later, on 12 February 2013, DPRK exploded a nuclear device for the third time. ${ }^{2}$ The US thinks that imposing sanctions including possible military actions can be instrumental in fostering change in the attitude of Pyongyang leaders, but China opposes this, as it thinks this would be ineffective and rather humiliating to North Korean leaders. However, China agreed to stand beside the US and other powers in condemning the irresponsible behavior of Pyongyang. The United Nations Security Council passed Resolution 2094 on 7 March 2013, imposing sanctions in the economic, financial and political arenas. Overall, the sanctions imposed were relatively mild, and thus cannot

2 North Korea has previously exploded twice its nuclear devices in October 2006 and May 2009. 
be really instrumental in inducing changes within the Pyongyang regime. At the same time, Pyongyang declared that the Armistice agreement of Korea was void. It withdrew its representation office from Panmunjom, and the telephone line for liaison between the two Koreas located at Panmunjom was cut off.

The PRC government has been patiently encouraging DPRK to adopt the Chinese way to modernization through open door and reform policies without upsetting the communist-dominated political institutions, but apparently Pyongyang does not regard the current Chinese model of development as "socialism". It is particularly cautious about the establishment of special economic zones in order to attract investments from China. Optimism was expressed in the Chinese media when new foreign investment laws were enacted in March 2012 for the two special economic zones established in Rason in the northeastern part of Korea, and Hwanggumpyong and Wihwa Island at the Yalu River, just next to the Chinese border. In 2011, trade between North Korea and China accounted for $60 \%$ of North Korea's total trade, and Chinese companies are keen to extract rare earth in the DPRK, one of the few products of the country that can be bought (Committee on Foreign Relations, 2012, p. 7). China supplies $95 \%$ of DPRK's energy, $80 \%$ of its consumer goods, and $45 \%$ of its food (Bajoria \& Xu, 2014). The increasing participation of China in North Korea's domestic economic development might be just an extension of the Chinese leadership's thinking to help developing the less developed regions within China, such as Tibet and Xinjiang, through investments and construction of infrastructure. This has attracted the attention of US researchers, who claim that "China-launched investment and trade offensive directed at North Korea reflected an incremental economic integration with the North. [...] China quietly establishing an extensive business and trade infrastructure with North Korea that China will be prepared to protect" (Committee on Foreign Relations, 2012, p. 5). However, given the high degree of skepticism and cautiousness of North Korean authorities regarding China's maneuvers, we have reasons to be doubtful of such diagnosis. The influence of China towards the domestic economy of its communist neighbor is seriously constrained.

An Indian observer said, "as a responsible world power, China would like its influence to prevail on its immediate neighbor. Helplessness regarding North Korea does not befit China's image as a global power. However, China is acutely aware that the moment it tries to implement the West's agenda with North Korea, it will lose influence with Pyongyang." (Chakravorty, 2013, p. 39)

Helping to stabilize a regime that is the source of serious instability in the Korean Peninsula, yet being unable to foster evolutionary domestic changes within North Korea, simply illustrates the fact that even with growing power and 
capability, China is not yet able to induce any significant change to the status quo. Pyongyang obtains the critical assistance from Beijing, but diplomatically it acts unilaterally according to its own interests, irrespective of China's feelings. This puts China into an enormous diplomatic dilemma.

2017, the first year after Donald Trump's advent to power, witnessed a series of missile launches by Pyongyang, but both Trump and Kim Jong-un need to successfully achieve diplomatic breakthrough so as to appease their domestic audiences respectively. Their mutual wish to meet eventually resulted in their Singapore summit meeting in June 2018. The US did not obtain any commitment from North Korea on total nuclear disarmament, which should be "comprehensive, verifiable, irreversible". However, the summit was a great success for Kim as North Korea has been longing for bilateral negotiations with the US on an equal basis since the 1990s, while the US leaders in the past always insisted that high-level meetings and normalization of relationship cannot be achieved before total denuclearization. The second summit, held in Hanoi in February 2019, seemed to be a failure as it was cut short. According to Washington, no lifting of sanctions is possible unless full disarmament is effectuated, including the demolition of North Korea's enriched uranium program, while Pyongyang said that it was merely asking for partial lifting of sanctions in exchange for the destruction of the Nyonbyon reactors. In any case, the middle-man role of China is further "marginalized", as the US and North Korea can maintain high-level contacts and continue to express their goodwill for peace and negotiation. Despite the UN sanctions in place, Beijing continues to covertly provide assistance to Pyongyang in various aspects, so as to continue to exert its influence over North Korea's plans for the future.

\section{Revival of nationalism in Sino-Japanese relations: historical injuries and security dilemma}

Economic integration between China and Japan does not necessarily produce the 'spillover effect' in facilitating mutual understanding and acceptance. Rather the opposite is true. Scholars have already proven that

the relationship between interdependence and conflict appears to be curvilinear, where low to moderate degrees of interdependence reduce the likelihood of dyadic disputes, and extensive economic linkages increase the possibility of militarized disputes. Extreme interdependence, whether symmetrical or asymmetrical, has the 
greatest potential for increasing the likelihood of conflict. (Barbieri, 1996)

This is contrary to the liberalist perspective. The relationship between China and Japan has been long dominated by political conflicts resulting from historical lessons. Economic interdependence cannot help resolve the conflicts, yet existing rivalry could cause a downturn of economic interdependence between the two nations even though both rely on each other economically.

Just like the US, after twenty years of stagnation, Japan is also suffering from relative decline. With a shrinking population (a decrease of 200,000 per year), a rapidly growing aging society, the lack of job opportunities for the young people, unending natural disasters, Japanese society is becoming more and more pessimistic regarding its future (Ting, 2013b). In addition, the government proves to be incompetent in solving the numerous problems. Many of the problems are structural and have their roots in the rigid societal structure and stagnant economy. Radical reforms are needed in order to restructure the societal and economic structure, but no Japanese Prime Ministers have succeeded in launching meaningful reforms, with the exception of the privatization of postal service when Premier Junichiro Koizumi was in power. In sharp contrast to the stagnation of Japan's development and the lack of vision for Japan's future, the Japanese people are witnessing the rapid rise of China and even the rise of their smaller neighbor, South Korea. There is a strong sense of crisis and powerlessness among ordinary Japanese people. In such circumstances, society is turning to the political right. A revival of the Japanese "grandeur" is the dream of many people and it has become the foundation of Japanese modern nationalism. The resort to nationalism and the urgent need for the revival of Japan paved the way for the success of Premier Shinzo Abe in returning to the political stage in December 2012.

Parallel to the revival of Japanese nationalism resulting from the stagnation of Japan's economy and society, is the development of Chinese nationalism which displays a kind of arrogance resulting from the "renaissance" of China after a century of national humiliation. On the one hand, the revival of Japanese nationalism is epitomized by the visit of the Japanese Prime Ministers, including Koizumi during the period 2001-2006 and Abe on 26 December 2013, to Yasukuni Shrine, the national shrine where the Japanese pay tribute to all those Japanese soldiers and nationals who died for the nation. On the other hand, in the eyes of the Asian neighbors, Chinese nationalism is expressed by Beijing's recent challenges to the status quo in East China Sea and South China Sea. The general perceptions of China's neighbors like Vietnam, the 
Philippines and Japan are that the increasing economic and military capabilities of China empower the Beijing leaders to become more assertive and aggressive in maritime and territorial issues. However, both Japan and China blame the belligerent attitude of the opposite side as the source of nationalism in their country. Japan has criticized the rapid rise of military expenditure as well as the lack of transparency in the growing capabilities of Chinese national defense, and Japan has no choice but to respond by significantly improving its naval and air power. Beijing feels critically offended by the increasing nationalistic attitude of the Japanese government and the revisionist view of history of the new Abe administration. Beijing is perplexed by the "alignment" of its Asian neighbors with Washington following its policy of "rebalancing" to Asia (Luttwak, 2012). It perceives this alignment as a kind of "containment" against the rise of China, despite the fact that China has been practicing a policy of "developing better relations with, appeasing, and enriching her neighbours" (Mulin, Anlin, Fulin). Popular nationalism in China continues to rise, as many Chinese nationals hold the rather simplistic and erroneous view that since China's GDP is number two in the world, China has already become the second most powerful nation in the world. As a result, they ask for a more assertive and even aggressive posture of the nation in response to the challenges from the US, Japan and other neighbors. The rise of popular nationalism in both China and Japan is closely related to the relative change in capabilities and shifting equilibrium of the two strongest powers in Asia (Huang \& Lv, 2011, p. 41).

The Chinese policy regarding the disputed maritime areas and the sovereignty of islands is epitomized by the following principle: "sovereignty belongs to me, putting aside the disputes, jointly developing the areas" (Shi, 2014, p. 22). During the normalization of the relationship between Japan and the PRC in 1972, Premier Tanaka raised the issue of Diaoyu Islands, but Zhou Enlai did not want to have this issue obstructing the normalization process, so he proposed to put it aside. This is considered to be a tacit consensus between the two governments, and later Deng Xiaoping reiterated the Chinese principle, emphasizing that the issue could still be put aside and let the future generations of leaders and people of both nations to solve the issue as they are more intelligent. If for both countries development around the Diaoyu Islands is deemed to be necessary, it could be executed jointly by the authorities concerned and benefits can be equally shared between the two. The Chinese attitude has always been the same. The Diaoyu Islands can be regarded as a kind of treasure that both countries want. In order to prevent the escalation of conflict, it is imperative for both parties to refrain from landing or occupying the islands, or even to sail within the territorial waters of the Islands, that is, within the 12 nautical miles from the 
Islands. Joint development in any case is referred to the maritime areas, such as fishing and exploitation of petroleum, and there is no point for both parties to station people on the Islands. Refraining from approaching and landing the Islands is considered by Beijing to be part of the tacit consensus between China and Japan.

However, from time to time the Japanese authorities allowed the right-wing activists to embark on the Islands. The most serious case happened in 1996 when Japanese activists painted the Japanese flag on the Islands and established a second lighthouse (the first one in 1988) in order to demonstrate that the Diaoyu Islands were under Japanese sovereignty. This provoked serious rebukes from people in Taiwan and Hong Kong and, as a consequence, some Chinese activists from these two enclaves sailed to Diaoyu Islands to "declare sovereignty". Even in such circumstances, no civilians from the Mainland were allowed to leave for Diaoyu Islands, and the official Chinese ships did not even appear in the neighboring waters. In other words, even if Japan appeared to be more aggressive, Beijing adhered to the "tacit consensus" of not approaching or "touching" the Islands. In February 2005, the lighthouse erected by the right-winged Japanese activists was placed under state control and protection (Beuket, 2011, p. 15). In spring that year, there were massive demonstrations in various cities of China against "Japanese militarism". But the Chinese official reaction to these manifestations was cautious. After the demonstrations continued for some days, the top Chinese leaders requested the demonstrators to return life to normal. Just like the demonstrations against the US in May 1999 and April 2001, the Beijing authorities worried that if the manifestations continued and remained uncontrolled, they would be targeted towards the central government in Beijing, by asking it to act more strongly against foreign interference. If the attention shifted from Tokyo to Beijing that would probably become another source of instability.

The status quo was changed when the Japanese central government decided to buy the Islands from private owners in September 2012. The pretext of the then Premier Yoshihiko Noda is that it is better to have the central government buying the Islands, rather than by the Mayor of Tokyo, Shintaro Ishihara, who is a well-known right-wing nationalist that would arouse more negative feelings among the Chinese. Beijing considers Noda's action as breaking the tacit consensus of the two governments, so it categorically changes its actions, albeit the principle of "setting aside the dispute" remains unchanged. Again, massive demonstrations took place all over China, but again, they were under scrutiny of the Beijing authorities. The author was in Hangzhou in late September 2013 and he witnessed a demonstration in the city. Interestingly, although the roads were closed and traffic was blocked for the demonstrators, the several hundred 
young demonstrators were simply marching in the streets, without shouting any slogans, or displaying any banners in order to show their disapprobation of Japanese aggressiveness. In front of them, there were police motorcycles that led the demonstration, and at the back there were two buses of policemen following the demonstrators. Obviously, the protest was closely monitored by the authorities and was not allowed to affect the stability of society. This suffices to prove that the Chinese government wishes to express its dissatisfaction, through accepting the requests for demonstrations from the masses, towards the unusual Japanese action of "nationalizing" the Diaoyu Islands. But Beijing does not allow the domestic anti-Japanese movements to get out of control. It simply wishes that the Japanese government would return to the original tacit consensus in place since 1972.

Japanese scholars tend to think that the change of attitude of the Chinese government from April to August 2012 illustrates the divergences among the Chinese leaders, between the "non-nationalist" President Hu Jintao and Premier Wen Jiabao, and the nationalist President Jiang Zemin and Vice-President Zeng Qinghong (Takeuchi, 2014, p. 28). During the period of 2006 to 2012, under the leadership of $\mathrm{Hu}$, Sino-Japanese relations were found to be rather cordial but $\mathrm{Hu}$ did not fully control a strong enough power base for him to advance his own policies. Jiang with Zeng represent the interests of "state capitalists". China only hardened its position in August after the summer conference at Beidaihe, while its position in April was relatively mild when Tokyo Major Ishihara proposed to buy the Diaoyu Islands. Beijing did not want Ishihara to buy the islands, and its reaction was "initially low key when the Japanese national government tried to buy the islands to prevent Ishihara from doing it" (Takeuchi, 2014, p. 29). However, the strong stance of nationalistic Chinese leaders like Jiang eventually prevailed and, as a result, Beijing's position was hardened in August.

Indeed, it is true that the best period in recent Sino-Japanese relations started in 2006 under the Hu administration. During that period, no demand for apology from the Chinese government was requested, while no Japanese prime ministers (altogether six of them) visited the Yasukuni Shrine from 2006 to 2012. Premier Hatoyama from the Democratic Party adopted a friendly attitude to China, while during the short tenure of Premier Fukuoda, the two governments even succeeded in achieving a "principled consensus" on 18 June 2008 to proceed on joint exploitation of natural resources at the East China Sea. The Chinese government even accepts Japanese investments in the oilfields that are found in the Chinese Maritime Exclusive Economic Zone. Nevertheless, in essence, although factions do exist within the core leadership of the Chinese Communist Party, it is difficult to imagine that $\mathrm{Hu}$ Jintao could accept the purchase of 
Diaoyu Islands by the Japanese government. Hu had the chance to meet Premier Noda in Vladivostok in September 2012, warning him that the purchase of the Islands was illegal and invalid. But two days later, on 4 September 2012, the decision was made. Former Chinese State Councilor Tan Jiaxuan made it clear that this "had caused the Chinese people to lose face and triggered their anger" (Przystup, 2013, p. 5). What is most striking for Chinese leaders and people is that Noda asserts there is no territorial dispute between the two nations and buying the Islands by the central government is just a domestic matter. This is unilateral destruction by Japan of the tacit consensus achieved since 1972.

In order to show its dissatisfaction, from September 2012 onwards, the Chinese government decided to send official ships to the territorial waters of Diaoyu Islands to declare its sovereignty; however, it still refrains from disembarking on the Islands. Since then, no Chinese civilians from the Mainland and even Hong Kong were allowed to land on the Islands, although previously some Hong Kong Chinese succeeded to sail to and disembark on the Diaoyu Islands in August 2012, apparently under the tacit consent of the central authorities in Beijing. Ships from the Chinese Maritime Surveillance and the Fisheries Law Enforcement Agency started to patrol in the surrounding areas of Diaoyu Islands from September 2012, and later the different administrations for maritime affairs have been merged into a new department, the Marine Police. Since December 2012, airplanes have been sent to provide surveillance of the Islands.

Since Abe became the Prime Minister, his "revisionist" approach to history has aroused worldwide attention and unease. He did even ask for a re-examination of the Kono statement on Comfort Women declared in 1993, and the Socialist Premier Murayama's apology offered in 1995 regarding the atrocities and damage caused by Japanese militarists in Asia. His high-profile visit to the Yasukuni Shrine in December 2013 was condemned by South Korea and China, and even the US expressed its "disappointment" about such a move, saying that this adds insult to injury. Since then there has been a well-coordinated action launched by Beijing in fighting an international public opinion war, with 59 Chinese Ambassadors contributing articles to the local newspapers condemning the Japanese path towards militarization. This has attracted rebukes from the Japanese diplomats, who wrote to the same newspapers criticizing China for challenging the status quo in East and South China Sea (Lin, 2014, p. 25). The Chinese decision that establishes the Air Defense Identification Zone (ADIZ) in East China Sea, and the establishment of the new regulations in managing traffics in South China Sea, entitled Regulations for the Management of Coastal Border Security and Public Order in Hainan Province, are considered not only by Japan but by other Asian states as posing a serious challenge to the status 
quo through forceful actions of China. The popular nationalism of China and the increasingly negative image of China as perceived by the others, render the Chinese public opinion efforts rather ineffective in convincing the Asian neighbors that China occupies a moral high ground. In any case, the Chinese foreign policy decision-makers prefer to be cautious as the military capabilities do not suffice to support aggressive activities against the neighbors. Notably the US-Japan alliance is still considered as the fundamental force that maintains stability of the vast Asia-Pacific region and the security of many Asian states.

The lack of regional multilateral security architecture is a fundamental reason for the general ill feeling surrounding the territorial disputes that happen between China and her neighbors, most notably Japan, the Philippines and Vietnam. There is an urgent need to establish confidence-building measures between China and the others, or at least some kinds of mechanisms that can alert the adversaries to prevent any miscalculations and misinterpretations of a country's real intentions. Both China and Japan have established new state institutions to strengthen their domestic coordination of policies relating to state security. Following the creation of the State Security Council in November 2013, the Japanese government passed three important documents on 17 December 2013. The first one is the 'National Security Strategy', which asks for reforming the 'Three Principles for the Export of Weapons'. The other documents include the revised version of 'National Defense Outline', and the new edition of 'Mid-Term Defense Plan', from 2014 to 2018. The new defense plan of Japan stresses the increasing pressure from China. As a result, it asks for "strengthening Japan's capabilities in the areas of Intelligence, Surveillance and Reconnaissance (ISR), its ability to respond to attacks on Japan's remote southern islands, ballistic-missile defense, cyber warfare, natural disasters, and the country's joint operations capabilities" (Mizokami, 2013). The defense budget will be increased 5\% over the next five years, to a total of 247 billion dollars. China's new National Security Committee under the leadership of State President and Party Chief Xi Jinping highlights the authorities' key concern regarding the domestic security and external security and the possible liaison between the two.

The possible reconciliation of the conflict between Japan and China depends on whether new thinking, or thinking outside the box, can liberate both parties from the security dilemma. This creative thinking requires leaders of both sides to be clear-sighted as well as use appropriate strategies to achieve a breakthrough in the deadlock. It also requires the leaders to possess the power in ascertaining that the strategies could be sustained (Bush, 2010, p. 334). According to a Chinese strategist, the reconciliation of Sino-Japanese relations should be founded on three achievements: mutual functional benefits, mutual political trust, and mutual 
strategic gains (Qi, 2014, p. 20). While economic interdependence has largely rendered mutual economic benefits to both parties, the mutual political distrust that has grown since the development of popular nationalism in both countries further aggravates the difficulties and uncertainties in the bilateral relationship.

\section{Conclusion}

The rise of China is a developmental process, and China's military, economic and technological capabilities have not yet arrived at a stage that enables Beijing to set the rules of the game, or international norms, for the global community. China's influence is increasing given its enormous trading transactions and massive investments overseas, but it is not yet ready to play the role of leader of the global system. In fact, if we treat the whole world as a global capitalist market, the US is clearly the true leader of capitalism, consistently initiating new ideas to raise the performance of private companies so as to significantly augment their profits. China uses market mechanisms, but the "state capitalists", that is, the state-owned enterprises that monopolize the key industries domestically and secure enormous profits, are not considered beneficial to the development of "perfect" capitalism as they imply the intervention of state or political power in the market. However, they are increasingly aggressive in overseas markets. Washington under the Obama administration attempted to use Trans-Pacific Partnership (TPP) negotiations to foster changes in the Asian nations, such as the privatization of state enterprises, and completely opening up their markets, including agriculture. In other words, the US urges them to move towards the perfect model of capitalism. Exercising leadership in the capitalist world and maintaining its status as superpower in military deployment are seen as symbols of American leadership in the world. China is far from such a position. As we can see from North Korea and Japan, the rise of China is not yet able to incur significant geo-political transformation in Northeast Asia, even though nationalists within China claim that their country should be more assertive and able to forge ahead in establishing a more favorable geopolitical environment.

The top security priority of North Korea is to establish a bilateral relationship with the US on an equal basis so as to eliminate hostilities from the US. Many aspire to see the PRC playing an intermediary role in between the US and the DPRK, but Chinese officials used to lament on the limitations of Beijing's influence in Pyongyang. The increasing economic and military capabilities of China cannot be instrumental in fostering significant changes within North Korea, especially 
when the latter is equipped with nuclear armaments that produce an "equalizer" effect in its relations with the greater powers. The relationship between DPRK and the US can be perceived in the same vein, as Pyongyang firmly believes that possessing nuclear capabilities is the most effective means to deter potential American invasion. Perhaps the best moments to eliminate the rudimentary nuclear facilities have already passed. All the neighboring powers, plus the US, must now consider how to deal with this new nuclear state, North Korea. It is troubling that the totalitarian regime in North Korea remains steadfast.

In the case of Japan, Premier Abe indicated in March 2014 that he was not going to revise the declarations made by Kono in 1993 and Murayama in 1995. Still, the revisionist historical view of the Abe administration would result in the promotion of national education, further "normalization" of its defense force, and the upgrade of its military facilities. The security dilemma between Japan and China will then be further enforced. In order to achieve a breakthrough, it is imperative for both countries to identify and develop complementary interests. After Trump's advent to power, both Japan and China have suffered from his protectionist measures under the "America First" policy. Since the two Asian economic powers have achieved a high degree of economic interdependence, their political relationship has been improving in recent years in response to their shared burden imposed by Trump.

Although China is clearly on the rise, the country has not yet arrived at a stage where it commands respect as a leader in the international community. Although a fast-growing power, it has enormous difficulties in dealing with the crises in the Korean Peninsula and the challenges of Sino-Japanese relations. A lack of soft power may be one of the reasons for this, as it has little to offer to the whole world in terms of ideas, culture, values and institutions. The rise of China has already rendered a more nationalistic and arrogant China, but the developing popular nationalism might just hinder a favorable solution to the problems impeding China's relationship with the outside world.

Dr. Wai Ting obtained his doctorate in political science and international relations from the University of Paris X, Nanterre. Formerly research fellow at the Institute of Southeast Asian Studies, Singapore, he is now professor of the Department of Government and International Studies, Hong Kong Baptist University. His research interests include China's domestic politics and foreign policies, and theories of international relations. He has published extensively on Sino-American relations, Sino-European relations, China and Asia, Chinese nationalism and visions of regional cooperation, Chinese nuclear strategy, and external relations and international status of Hong Kong. He has 
been a visiting professor at Ateneo de Manila University, Harvard University, Oxford University, Institut d'Etudes Politiques of Lille, and University Montesquieu Bordeaux IV.

\section{References}

Bajoria, J. \& Xu, B. (2014), The China-North Korea Relationship, Washington, DC: Council on Foreign Relations.

Barbieri, K. (1996), 'Economic interdependence: a path to peace or a source of interstate conflict,' Journal of Peace Research, vol. 33, no. 1, pp. 29-49. https://doi.org/10.1177/0022343396033001003

Beukel, E. (2011), Popular Nationalism in China and the Sino-Japanese Relationship: The Conflict in the East China Sea. An Introductory Study, DIIS Report 2011:01, Copenhagen: Danish Institute for International Studies.

Bisley, N. (2012), 'China's rise and the making of East Asia's security architecture,' Journal of Contemporary China, vol. 21, no. 73, pp. 10-34.

https://doi.org/10.1080/10670564.2012.627663

Bush, R. (2010), The Politics of Proximity: China-Japan Security Relations, Washington, DC: The Brookings Institution Press. [Chinese edition published by Yuan Liu Publishing, Taipei, 2012]

Chakravorty, S. (2013), China-Japan-Korea: Tangled Relationships, ORF Occasional Paper, no. 39, New Delhi: Observer Research Foundation.

Committee on Foreign Relations (2012), China's Impact on Korean Peninsula Unification and Questions for the Senate, Washington, DC, 11 December.

Dalton, T. \& Yoon, H. J. (2013), 'Reading into South Korea's nuclear debate,' PacNet Newsletter, Pacific Forum CSIS, 18 March.

Department of Defense (2014), Quadrennial Defense Review 2014, Washington, DC: US Department of Defense. Retrieved from http://www.defense.gov/pubs/2014 Quadrennial_Defense_Review.pdf [accessed 9 Jun 2015]

Gill, B. (2011), China's North Korea Policy: Assessing Interests and Influences, Special Report no. 283, United States Institute of Peace.

Huang, F. \& Lue, P. (2011), 'Investigation into China's security in Northeast Asia geopolitics,' Xiandai Guoji Guanxi [Contemporary International Relations], pp. $36-41$.

Lin, L. (2013), 'Analysis of the international strategic situation in 2013,' Xiandai Guoji Guanxi [Contemporary International Relations], December, pp. 9-19.

Lin, Q. (2014), 'The international politics of Yasukuni Shrine,' Mingbao Yuekan [Ming Pao Monthly], vol. 49, no. 4, pp. 24-26.

Liu, F. (2013), 'The US rebalance to Asia: slowing down and correcting deviations?' Guoji Wenti Yanjiu [International Studies], no. 155, pp. 81-93. 
Luttwak, E. N. (2012), The Rise of China vs. The Logic of Strategy, Cambridge, MA: The Belknap Press of Harvard University Press. https://doi.org/10.4159/ harvard.9780674067936

Mizokami, K. (2013), 'Inside Japan's new defense plan,' USNI News, 20 December. Retrieved from http://news.usni.org/2013/12/20/inside-japans-new-defense-plan [accessed 9 Jun 2015]

Park, J. (2013), China-US Relations in East Asia: Strategic Rivalry and Korea's Choice, Washington, DC: Center for Strategic and International Studies.

Przystup, J. J. (2013), '40th anniversary 'Fuggetaboutit!', Comparative Connections, vol. 14 , no. 3 , pp. 109-124.

Qi, H. (2014), 'Constructing the 'Diplomatic Strategy for the Great Border' that faces the future decade,' Shijie Zhishi [World Affairs], no. 1623 (16 February), pp. 20-21.

Shi, Y. (2014), 'The diplomacy of 'putting aside': sovereignty belongs to me, putting aside the disputes, jointly developing the areas,' Shijie Zhishi [World Affairs], no. 1623 (16 February), pp. 22-23.

Takeuchi, H. (2014), 'Sino-Japanese relations: power, interdependence, and domestic politics,' International Relations of the Asia-Pacific, vol. 14, no. 1, pp. 7-32. https://doi.org/10.1093/irap/lct023

Ta Kung Pao (2013), 'The last words of Zang Song-thaek: Kim Jung-un has no way to solve the economic problems of North Korea. Ta Kung Pao Online News, 17 December. Retrieved from http://news.takungpao.com.hk/world/focus/2013-12/2111523. html [accessed 9 Jun 2015]

Ting, W. (2009), 'Thinking about the soft power of China,' Ershiyi Shiji [21st Century Bimonthly], no. 116 (December), pp. 6-10.

Ting, W. (2013a), The 'Grand Strategy' and foreign policies of China during the rise,' in W. George \& F. Chen (eds.) Dongxifang wenhua yu waijiao fanglue bijiao [A Comparison of Eastern and Western Culture and Diplomatic Strategies: Theoretical Studies], Macau: University of Macau, pp. 231-242.

Ting, W. (2013b), 'China's naval development and the evolving security dilemma in East Asia,' Comprehensive Security in Northeast Asia: Maritime Security, KAS Journal on Contemporary Korean Affairs, no. 1, Konrad Adenauer Stiftung in Korea, pp. 23-41.

Wang, W. (2013), 'A review of recent security situation in Northeast Asia and Sino-US strategic relations,' Xiandai Guoji Guanxi [Contemporary International Relations], no. 284 , pp. $40-46$.

Wen Wei Po (2014), 'North Korea would execute 200 followers of Zang Song-thaek,' Wen Wei Po Online News. Retrieved from http://news.wenweipo.com/2014/04/04/ IN1404040008.htm [accessed 9 Jun 2015] 
Xia, M. et al. (2014), 'Northeastern Asian perceptions of China's rise: to what extent does economic interdependence work?' Modern China Studies, vol. 21, no. 2, pp. 87-132.

Zhang, L. (2013), 'Maintaining a denuclearized Korean Peninsula is entering into a critical period of success or failure,' Dongbeiya Luntan [Northeast Asia Forum], no. 3, pp. 13-24.

Zhu, L. (2011), 'Peace and prosperity of Northeast Asia and the role of China,' Dongya Lunwen [East Asian Papers], no. 87, pp. 1-18. 